$\underline{\text { Review Article }}$

\title{
CHEMICAL CONSTITUENTS AND PHARMACOLOGICAL EFFECTS OF LEPIDIUM SATIVUM-A REVIEW
}

\author{
ALI ESMAIL AL-SNAFI \\ Department of Pharmacology, College of Medicine, Thi qar University, Iraq \\ Email: aboahmad61@yahoo.com
}

Received: 10 Aug 2019, Revised and Accepted: 07 Oct 2019

\begin{abstract}
Lepidium sativum contained many bioactive constituents included cardiac glycoside, alkaloids, phenolic, flavonoids, cardiotonic glycosides, coumarins, glucosinolates, carbohydrates, proteins and amino-acids, mucilage, resins, saponins, sterols, tannins, volatile oils, triterpene, sinapic acid and uric acid. The pharmacological investigation revealed that Lepidium sativum possessed antimicrobial, antidiabetic, antioxidant, anticancer, reproductive, gastrointestinal, respiratory, anti-inflammatory, analgesic, antipyretic, cardiovascular, hypolipidemic, diuretic, central nervous, fracture healing and protective effects. The current review discussed the chemical constituents and pharmacological effects of Lepidium sativum.
\end{abstract}

Keywords: Constituents, Pharmacology, Lepidium sativum

(C) 2019 The Authors. Published by Innovare Academic Sciences Pvt Ltd. This is an open-access article under the CC BY license (http://creativecommons.org/licenses/by/4.0/) DOI: http://dx.doi.org/10.22159/ijcpr.2019v11i6.36338

\section{INTRODUCTION}

Herbal medicine is the oldest form of healthcare known to mankind. Herbs had been used by all cultures throughout history. Plants are a valuable source of a wide range of secondary metabolites, which are used as pharmaceuticals, agrochemicals, flavours, fragrances, colours, biopesticides and food additives [1-6]. The phytochemical analysis of Lepidium sativum showed that it contained cardiac glycoside, alkaloids, phenolic, flavonoids, cardiotonic glycosides, coumarins, glucosinolates, carbohydrates, proteins and amino-acids, mucilage, resins, saponins, sterols, tannins, volatile oils, triterpene, sinapic acid and uric acid. The pharmacological investigation revealed that Lepidium sativum possessed antimicrobial, antidiabetic, antioxidant, anticancer, reproductive, gastrointestinal, respiratory, anti-inflammatory, analgesic, antipyretic, cardiovascular, hypolipidemic, diuretic, central nervous, fracture healing and protective effects. The current review will highlight the chemical constituents and pharmacological effects of Lepidium sativum.

\section{Plant profile}

\section{Synonyms}

Arabis chinensis, Cardamon sativum, Crucifera nasturtium, Lepia sativa,Lepidium hortense, Lepidium sativum var. crispum, Lepidium sativum subsp. sativum, Lepidium sativum var. spinescens, Lepidium sativum subsp. spinescens, Lepidium spinescens, Nasturtium crispum, Nasturtium sativum, Nasturtium spinescens, Thlaspi nasturtium, Thlaspi sativum and Thlaspidium sativum [7]

\section{Taxonomic classification}

Kingdom: Plantae, Subkingdom: Viridiplantae, Infrakingdom: Streptophyta, Superdivision: Embryophyta, Division: Tracheophyta, Class: Magnoliopsida, Order: Brassicales, Family: Brassicaceae, Genus: Lepidium, Species: Lepidium sativum [8].

\section{Common names}

Arabic: habb al-rashad, rashad, thufa; Bengali: halim; Chinese: jia du xing cai; English: garden cress, pepperwort, tongue cress, town cress; French: cresson alénois; German: Gartenkresse; Hindi: chandrasur; Italian: agretto, Portuguese: agrião, mastruço; Swedish: smörgåskrasse [9].

\section{Distribution}

It is distributed in Africa (Egypt, Ethiopia and Kenya), Asia (Kuwait, Oman, Saudi Arabia, United Arab Emirates, Yemen, Afghanistan, Iran, Iraq, Palestine, Jordan, Lebanon, Syria, Turkey, Pakistan, China, Japan, India), Europe (Britain, France, Italy, Germany), Australasia
(Australia and New Zealand), Northern America (Canada and United States) and Southern America (Argentina and Chile) [9].

\section{Description}

Lepidium sativum is an erect, branched, glabrous herb with $60 \mathrm{~cm}$ height. Leaves are entire or pinnately dissected, variously lobed often with linear segments; up to 5-6 cm long and lobes are 0.7-1.2 to 0.3-0.6 $\mathrm{cm}$ size, upper leaves usually entire and $2-3 \mathrm{~cm}$ long, oblanceolate, sessile. The basal leaves have long petioles and are lyrate Pinnatipartite; the couliner leaves are lanceonate. The inflorescence is in dense racemes. The flowers have white or slightly pink petals, measuring $2 \mathrm{~mm}$. The siliquae measure 5 to $6 \mathrm{~mm}$, are elliptical elates from the upper half and glabrous. Racemes are 7 to $15 \mathrm{~cm}$ long axillary and terminal; flowers are white or pale pink; pedicels are $3-5 \mathrm{~mm}$ long. Pods are obovate or broadly elliptical, roundate, emarginated slightly but thickly winged above Fruit a round or ovate, flattened silique 4-6 $\mathrm{mm} \times 3-5.5 \mathrm{~mm}$, pale green to yellowish, margins wing-like, apex emarginate, dehiscing by 2 valves, usually 2 -seeded [10-12].

\section{Traditional uses}

The seeds of Lepidium sativum were used as an aperient, diuretic, tonic, demulcent, carminative, galatogogue, emmenagogue, to cure throat diseases, uterine tumour, nasal polyps and breast cancer. Seeds were supplemented in the diet of lactating women to increase the milk secretion during the postnatal period. Seeds also applied as a poultice to pains, hurts, sprains, in the treatment of bacterial and fungal infections [13-16].

The seeds were also used for the treatment of fracture healing in Saudi traditional medicine [17]. In Unani system of medicine, seeds and leaves were used as diuretics, aperient and aphrodisiac, and were recommended in inflammation, bronchitis, rheumatism and muscular pain [18]. In Turkish folk medicine, Lepidium sativum was used as to enhance digestion, as carminative and appetizer [19]. The plant was eaten and seed oil was used in treating dysentery, diarrhea and migraine [20].

The mucilage in the outer seed was used as a substitute for tragacanth and gum Arabic [21].

\section{Parts used medicinally}

Seeds, oils and leaves $[15,18,20]$.

\section{Physicochemical characteristics}

Physicochemical characteristics of Lepidium sativum were: total ash: $1.57 \%$, acid insoluble ash: $0.74 \%$, water soluble ash: $0.83 \%$, successive 
extraction (petroleum ether: $2.05 \%$, chloroform: $2.67 \%$, methanol: 9.09\%, water: alcohol (50:50): 4.94\% and water: 0.294\%) [22].

Physicochemical characteristics of Lepidium sativum whole meal endosperm and bran were: moisture content $4.14 \pm 0.05,2.58 \pm 0.01$ and $4.27 \pm 0.01 \%$; protein: $22.47 \pm 0.78,27.74 \pm 0.02$ and $12.58 \pm 0.21 \%$; fat: $27.48 \pm 0.14, \quad 33.06 \pm 0.16$ and $6.34 \pm 0.19 \%$; carbohydrates: $34.24 \pm 0.92,28.45 \pm 0.21$ and $50.31 \pm 0.08 \%$; crude fiber: $7.01 \pm 0.08$, $4.00 \pm 0.13$ and $14.29 \pm 0.06 \%$; ash: $4.65 \pm 0.09,4.06 \pm 0.08$ and $6.19 \pm 0.01 \%$; insoluble dietary fiber: $28.49 \pm 0.38,13.10 \pm 0.62$ and $74.07 \pm 1.48 \%$; soluble dietary fiber: $1.51 \pm 0.09,0.50 \pm 0.01$ and $0.93 \pm 0.01 \%$; total dietary fiber: $30 \pm 0.47,13.6 \pm 0.62$ and $75 \pm 1.49 \%$; energy $474 \pm 1.06,523 \pm 0.82$ and $363 \pm 0.87 \mathrm{Kcal}[23]$.

The seed oil extracted by solv+ent extraction, supercritical $\mathrm{CO}_{2}$, and cold expression were $21.54,18.15$, and $12.60 \%$ dry weight, respectively. Physicochemical parameters of oils extracted by solvent extraction, supercritical $\mathrm{CO}_{2}$, and cold expression were, respectively: refractive index (nDt):1 $1.47 \pm 0.001,1.47 \pm 0.003$ and $1.47 \pm 0.002$; specific gravity $(\mathrm{g} / \mathrm{ml}): 0.91 \pm 0.001,0.90 \pm 0.001$ and $0.91 \pm 0.001$, viscosity $(\eta): 64.3 \pm 0.90,55.5 \pm 0.37$ and $53.8 \pm 0.6$; peroxide value (mequiv peroxide/kg oil): $0.70 \pm 0.13,4.09 \pm 0.16$ and $2.63 \pm 0.81$; free fatty acid (\% oleic): $0.28 \pm 0.02,0.39 \pm 0.04$ and $1.52 \pm 0.28$; saponification value $(\mathrm{mg} \mathrm{KOH} / \mathrm{g}): 178.85 \pm 0.46$, $182.23 \pm 0.73$ and $174 \pm 0.82$; unsaponifiable matter (g \%): $1.65 \pm 0.24$, $1.39 \pm 0.10$ and $1.16 \pm 0.30$; iodine value ( $\mathrm{g}$ of $\mathrm{I}_{2}$ absorbed/100 g): $122 \pm 0.70,131 \pm 3.26$ and $123 \pm 1.68[24,25]$.

\section{Chemical constituents}

The preliminary phytochemical analysis of Lepidium sativum showed that it contained cardiac glycoside, alkaloids, phenolic, flavonoids, cardiotonic glycosides, coumarins, glucosinolates, carbohydrates, proteins and amino-acids, mucilage, resins, saponins, sterols, tannins, volatile oils, triterpene, sinapic acid and uric acid [22, 26-28].

The quantitative analysis of Lepidium sativum seeds showed that the seeds contained protein $(24.2 \pm 0.5 \%)$, lipids $(23.2 \pm 0.2 \%)$, carbohydrates $(30.7 \pm 1.2 \%)$, fiber $(11.9 \pm 0.4 \%)$, ash $(7.1 \pm 0.1 \%)$, moisture $(2.9 \pm 0.1 \%)$, alkaloids $(0.40 \%)$, flavonoid $0.42 \%)$, saponin (2.8\%), tannin $(0.61 \%)$ and phenol $(0.004 \%)[29,30]$.

Wholemeal, endosperm and bran were analyzed for chemical composition. The whole meal, endosperm and bran contained 22.5, 27.7 and $12.6 \%$ protein, $27.5,33.1$ and $6 \%$ fat, 30, 13.6 and $75 \%$ dietary fiber, and $1193.00,945.15$ and $1934.57 \mathrm{mg} \%$ potassium, respectively. The most abundant amino acid was glutamic acid $(19.3 \%)$, the essential amino acid, leucine was the highest $(8.21 \pm 0.01 \%)$ and methionine was the lowest $(0.97 \pm 0.02 \%)$. The major fatty acid was linolenic acid (30.2\%) and the lowest was erucic acid (3.9\%). Bran having high water holding capacity and high dietary fiber [23].

The seed proteins contained the following essential amino acids: (histidine $3.87 \pm 0.14$, threonine $2.66 \pm 0.09$, arginine $4.51 \pm 0.03$, valine $8.04 \pm 0.03$, methionine $0.97 \pm 0.02$, phenylalanine $5.65 \pm 0.03$, isoleucine 5.11 \pm 0.03 , leucine $8.21 \pm 0.01$ and lysine $6.26 \pm 0.39$ $\mathrm{mg} / 100 \mathrm{~g}$ ); and nonessential amino acids: (aspartic acid 9.76 \pm 0.03 , glutamic acid $19.33 \pm 0.19$, serine $4.96 \pm 0.09$, glycine $5.51 \pm 0.07$, alanine $4.83 \pm 0,02$, tyrosine $2.69 \pm 0.09$ and proline $5.84 \pm 0.38$ $\mathrm{mg} / 100 \mathrm{~g}$ ). The seed also contained fatty acid: (palmitic acid $10.30 \pm 0.12$, palmitoleic acid $0.70 \pm 0.30$, stearic acid $1.90 \pm 0.19$, oleic acid $30.50 \pm 0.16$, linoleic acid $8.60 \pm 0.38$, linolenic acid $32.18 \pm 0.59$, arachidic acid $2.10 \pm 0.57$ and eicosaenoic aci $13.40 \pm 0.66 \%$ ); and mineral (calcium 266.35, copper 5.73, iron 8.31, magnesium 339.23, manganese 2.00 , phosphorus 608.63 , potassium 1236.51, sodium 19.65 and zinc $6.99 \mathrm{mg} / 100 \mathrm{~g})[24,31,32]$.

Fatty acid composition of Lepidium sativum seeds oil from Saudi Arabia included: (myristic 1.50, palmitic 8.80, stearic 3.49, oleic 23.49, linoleic 11.35 , linolenic 30.07 , arachidic 4.06 , eicosenoic 12.60 , erucic 4.64 , saturated fatty acids 17.85 , unsaturated fatty acid 82.15\%). Amino acid composition of Saudi Arabia Lepidium sativum seeds: (essential amino acids: lysine $2.26 \pm 0.390$, threonine $5.39 \pm 0.014$, valine $6.24 \pm 0.007$, methionine $1.06 \pm 0.000$, cysteine 0.80 , methionine+cysteine 1.86 , isoleucine $5.21 \pm 0.014$, leucine $9.03 \pm 0.007$, phenylalanine $5.80 \pm 0.004$, tyrosine $3.82 \pm 0.000$, phenylalanine+tyrosine 9.62, histidine $3.51 \pm 0.007 \%$ ) and (nonessential amino acids: arginine $2.89 \pm 0.000$, aspartic acid $11.47 \pm 0.014$, glutamic acid $19.68 \pm 0.028$, glycine $6.49 \pm 0.014$, alanine $5.85 \pm 0.007$, serine $5.30 \pm 0.007 \%$ ), and mineral composition: (potassium 785.0 \pm 7.51 , phosphorus $616.50 \pm 9.67$, calcium $253.0 \pm 1.04$, sodium $40.50 \pm 0.05$, iron $53.81 \pm 0.04$, copper $1.90 \pm 0.09$, zinc $4.10 \pm 0.07 \%$ ) [33].

The GC-MS spectrum of Lepidium sativum seed oil from Saudi Arabia revealed the presence of 16 components. The constituents included: $\beta$-amyrine $(31.33 \%), 9,12,15$-octadecatrienoic acid (15.97\%), 9octadecenoic acid methyl ester (11.93\%), $\alpha$-amyrine (9.32\%), 11eicosenoic acid $(6.64 \%)$, 9,12-octadecadienoic acid methyl ester (6.03\%), hexadecanoic acid (5.24\%), 13-docosenoic acid (2.64\%), Urs-12-en-24-oic acid,3-oxo-, methyl ester (2.52\%); 9octadecenamide $(2.32 \%)$, eicosenoic acid $(1.93 \%)$, methyl stearate (1.75\%), phenol, 2,2-methylenebis[6-(1,1-dimethyl (0.96\%), docosanoic acid, methyl ester $(0.69 \%)$, butylated hydroxytoluene $(0.42 \%)$ and 1s,R,7R,11R-1,3, 4, 7-tetramethyltricylo (0.31\%) [34].

Lepidium sativum seeds also contained heavy metal: cadmium: $0.24 \pm 0.02$, lead: $0.42 \pm 0.14$, arsenic: $0.48 \pm 0.06$ and mercury: $0.38 \pm 0.06 \mathrm{ppm}[22]$.

Analysis of methanolic seeds extract of Lepidium sativum, showed that the extract contained 46 compounds included deoxyspergualin, 6-oxabicyclo[3.1.0] hexan-3-one, 2-furancarboxaldehyde, 5-methyl, 9Oxabicyclo[3.3.1] honane-2,6-diol, glycyl-dl-serine, 2-hydroxy-1,1,10trimethyl-6,9-epidioxydecalin, methyl nicotinate, 4H-pyran-4-one, 2,3dihydro-3,5-dihydroxy-6-methyl-, thiocyanic acid, octyl ester, maltose, benzofuran,2,3-dihydro, 5-hydroxymethylfurfural, 2-methoxy-4vinylphenol, ascaridole epoxide, phenol, 2-methoxy-5-(1-propenyl)-, (E), $\alpha$-D-glucopyranoside, O- $\alpha$-D-glucopyranosyl-(1. fwdarw)- $\beta$-D-fruc, 2h-Indeno[1,2-b]furan-2-one,3,3a,4,5,6,7,8,8b-octahydro-8,8-dim,

limonen-6-ol, pivalate, (5ß)Pregnane-3,20ß-diol, 14 $\alpha, 18 \alpha$-[4-methyl3-oxo-(1-oxa-4-azabul, cinnamic acid, 4-hydroxy-3-methoxy-, \{5hydroxy-2-hydroxymethyl, 9-oximino-2,7-diethoxy fluorene, Phorbol, Streptovitacin A, 4,25-secoobscurinervan-4-ol,6,7-didehydro-22-ethyl15,16-dimethy, desulphosinigrin, d-mannose, methyl (1-0-retinyl2,3,4-triacetyl-ß-D-glucopyran) urinate, tetraacetyl-d-xylonic nitrile, dasycarpidan-1-methanol, acetate (ester), octadecanoic acid, 1Hcyclopropa[3,4]benz[1,2-e]azulene-5,7b,9,9a-tetrol,1a,1b,4,4a,

oxiraneoctanoic acid 3-octyl-,cis, 9-octadecenamide, (Z), octadecanal, 2-bromo, tributyl acetylcitrate, pyrrolidine, 1-(1-oxo-7,10hexadecadienyl), 8H-Azecino[5,4-b]indol-8-one, 5-ethylidene1,2,3,4,5,6,7,9-octahy, 16-Nitrobicyclo[10.4.0] hexadecane-1-ol-13-one, 2H-benzo[f]oxireno[2,3-E]benzofuran-8(9H)-one, 9-[2-(dimethylan, pregn-5-ene-3,8,11,12,14,20-hexol, $\quad(3 \beta, 11 \alpha, 12 \beta, 14 \beta, 20 R), \quad$ tocopherol, vitamin E, 6,7-epoxypregn-4-ene-9,11,18 triol-3,20-dione, 11,18-diacetate, stigmasterol, 9,19-cyclolanostane-3,7-diol and ergosta-5,22,-dien-3-ol,acetate, (3ß,22E) [35].

$\beta$-sitosterol and some phytoestrogens were isolated from Lepidium sativum. The amount of $\beta$-sitosterol was estimated to be about $0.20 \% \mathrm{w} / \mathrm{w}$ for seed powder and $0.024 \% \mathrm{w} / \mathrm{w}$ for callus powder of Lepidium sativum. Daidzein and formononetin were also isolated from the samples of Lepidium sativum [36].

Lepidium sativum ethanolic extract contained total phenolics $4.46 \pm 0.14$ to $11.03 \pm 0.75$ (mg GAE/g dw plant material) and flavonoids of $3.57 \pm 1.2$ to $4.79 \pm 0.24$ (mg QE/ $100 \mathrm{~g} \mathrm{dw}$ plant material). Phenolics identified in the ethanolic extract of Lepidium sativum were kaempferol, coumaroylquinic acid, $p$-coumaroyl glycolic acid and caffeic acid[37-38]. The isoflavonoids: 5,6dimethoxy-2',3'-methylenedioxy-7-C- $\beta$-d-gluco-pyranosyl

isoflavone, 7-hydroxy-4',5,6-trimethoxy isoflavone and 7-hydroxy5,6-dimethoxy-2',3'-methylenedioxyisoflavone were isolated from Lepidium sativum [39].

The seeds of Lepidium sativum also contained dimeric imidazole alkaloids, lepidine B, C, D, E and F and in semilepidinoside A and B [40].

Fractionation of the glucosinolate contents of the seeds of Lepidium sativum revealed the isolation of glucotropaeolin and 2-Phenyl ethyl glucosinolate, while, fractionation of the glucosinolate contents of the fresh herb revealed the presence of 2-ethyl butyl glucosinolate, methyl glucosinolate, butyl glucosinolate and glucotropaeolin [41]. 
$36.76 \% \mathrm{~g} / \mathrm{g}$ dry weight mucilage was obtained from the callus culture of Lepidium sativum. The mucilage produced by callus culture was nearly three times more than the mucilage yield of the seeds. The (glucose, arabinose, mannose, and galactose) were 43.4, 195.3 and $86.2 \mathrm{mg} / \mathrm{g}$ dry weight in the mucilage originated from seed, callus leaf and callus hypocotyl, respectively [42].

The percentage yield of total alkaloid in the Lepidium sativum seeds was $0.23 \% \mathrm{w} / \mathrm{w}$. GC-MS analysis revealed identification of 15 compounds in total alkaloidal extract of Lepidium sativum seeds. The compounds were: (Z)-5,11,14,17-eicosatetraenoate (10.24\%), guanosine (9.29\%), dodecanamide, $\mathrm{n}$-(2-hydroxyethyl) (7.48\%), hexadecanoic acid, 2-hydroxy-1-(hydroxymethyl) ethyl ester (7.13\%), 1-(1-adamantyl)-3-(1-piperidinyl)-1-propanone (6\%), hexadecanoic acid (5.33\%), 3-butylindolizidine (4.80\%), 9,12-octadecadienoic acid (Z,Z)-, 2-hydroxy-1-hydroxymethyl (4.79\%), 3-methyl alpha.-dglucopyranoside $(1.81 \%)$, stigmast-5-en-3-ol, (3. beta.) (3.58\%), soyasapogenol B $(1.15 \%)$, stigmasterol (1.07\%), fucosterol $(3.29 \%)$, gamma-tocopherol (5.04\%) and squalene (3.44\%) [43].

\section{Pharmacological effects}

\section{Antimicrobial effects}

The antimicrobial activities of methanolic seed extract of Lepidium sativum was studied against eleven bacterial strains (Salmonella typhi, Streptococcus pneumonia, Pseudomonas eurogenosa, Staphylococcus epidermidis, Escherichia coli, Bacillus subtilis, Proteus mirabilis, Streptococcus pyogenes, Staphylococcus aureus, Streptococcus faecalis and Klebsiella pneumonia) and fourteen fungal strains (Aspergillus niger, Aspergillus terreus, Aspergillus flavus, Aspergillus fumigatus, Candida albicans, Saccharomyces cerevisiae, Fusarium sp., Microsporum canis, Streptococcus faecalis, Mucor sp., Penicillium expansum, Trichoderma viride, Trichoderma horzianum and Trichophyton mentagrophytes). Antifungal study showed that the methanolic seed extract of Lepidium sativum was active against Aspergillus flavus, Aspergillus fumigates, Candida albicans and Saccharomyces cerevisiae with zones of inhibition of $7.01 \pm 0.11$, $7.00 \pm 0.11, \quad 6.99 \pm 0.14$ and $7.00 \pm 0.17 \mathrm{~mm}$, respectively. An antibacterial study showed that the methanolic seed extract of Lepidium sativum produced diameters of inhibition zones ranged from $6.03 \pm 0.27$ to $0.04 \pm 0.01 \mathrm{~mm}$ against the tested bacteria [35].

The antimicrobial effects of extracts of Lepidium sativum were investigated against Bacillus subtilis, Staphylococcus aureus, Escherichia coli, Proteus vulgaris, Pseudomonas aeruginosa, Candida albicans and Aspergillus niger. The methanolic extract of Lepidium sativum possessed antimicrobial activity against Candida albicans (21 $\mathrm{mm})$ and Proteus vulgaris $(20 \mathrm{~mm})$, Bacillus subtilis $(13 \mathrm{~mm})$, Staphylococcus aureus $(13 \mathrm{~mm})$, Escherchia coli $(13 \mathrm{~mm})$, Pseudomonas aeruginosa $(13 \mathrm{~mm})$ and inactive against Aspergillus niger. The chloroform extract showed very low activity against Staphylococcus aureus $(12 \mathrm{~mm})$ and Pseudomonas aeruginosa (12 $\mathrm{mm}$ ), with no activity against Bacillus subtilis, Escherchia coli, Proteus vulgaris, Candida albicans and Aspergillus niger. The water extract showed antimicrobial activity against Bacillus subtilis $(15 \mathrm{~mm})$ and Escherchia coli $(15 \mathrm{~mm})$, with no effect against Staphylococcus aureus, Proteus vulgaris, Candida albicans and Aspergillus niger [44].

The antimicrobial activities of extracts of Lepidium sativum seeds was studied against reference microorganisms [Pseudomonas aeruginosa (NCTC 10662), Staphylococcus aureus (ATCC 25923), Streptococcus pyogenes (ATCC 12344), Escherchia coli (ATCC 25922) and Klebsiella pneumonia (ATCC 10031)] and five clinical isolated MDR bacteria [S. aureus, S. pyogenes, E. coli, P. aeruginos and, $K$. pneumonia]. MBC and MIC values of ethanol extract of Lepidium sativum were identical for ATCC E. coli, ATCC S. aureus, ES $\beta$ L E. coli, and $\mathrm{M} \beta \mathrm{L}$ and $P$. aeruginosa $(3.13,6.25,12.5$, and $25 \mathrm{mg} / \mathrm{ml}$, respectively), while MBC values were slightly higher for both NCTC P. aeruginosa and MRSA (25 mg/ml; MIC $12.5 \mathrm{mg} / \mathrm{ml}$ ) and ATCC $K$. pneumonia $(12.5 \mathrm{mg} / \mathrm{ml}$; MIC $6.25 \mathrm{mg} / \mathrm{ml})$. The ethanol extract of Lepidium sativum produced the greatest inhibition zone $(15.5 \mathrm{~mm})$ against E. coli ATCC 25922 [45].

The antimicrobial activities of the aqueous extract of Lepidium sativum were studied against Bacillus subtillis, Proteus vulgaris,
Staphylococcus aureus, Escherichia coli, Pseudonomas aeruginosa, Salmonella typhi, Aspergillus niger and Candida albicans. The aqueous extract showed antimicrobial activities against Bacillus subtillis: $11 \mathrm{~mm}$; Proteus vulgaris: $13 \mathrm{~mm}$ and Staphylococcus aureus: $8 \mathrm{~mm}[30]$.

The antimicrobial effects of seed extracts of Lepidium sativum were investigated against Escherichia coli (MTCC No. 43), Staphylococcus aureus (MTCC No. 3160), Streptococcus mutans (MTCC No. 1943), Candida albicans (MTCC No.3017) and Pseudonomas aeruginosa (MTCC No. 2295). Lepidium sativum ethanolic seeds extracts possessed antimicrobial effects against Gram-positive and negative bacteria and ineffective against the fungal isolates. Methanol extract exhibited the highest zone of inhibition against Streptococcus mutans (31 $\mathrm{mm})$ followed by Pseudomonas aeruginosa $(17 \mathrm{~mm})$, Candida albicans $(15.5 \mathrm{~mm})$, Staphylococcus aureus $(15 \mathrm{~mm})$ and Escherichia coli $(12.5 \mathrm{~mm})$. The ethanol extract showed greater zone of inhibition against Pseudonomas aeruginosa $(18 \mathrm{~mm})$. Hexane extract exhibited the greatest zone of inhibition against Candida albicans (16 $\mathrm{mm})$ [46].

The antimicrobial activity of the petroleum ether, methanol and water extracts $(2.5,5$ and $10 \%)$ of Lepidium sativum seed extracts was tested against Staphylococcus aureus, Escherichia coli, Klebsiella pneumonae, Proteus vulgaris, Pseudomonas aeruginosa and Candida albicans. The petroleum ether extracts of Lepidium sativum seeds in different concentrations showed antimicrobial activity against all the tested microorganisms with strong anti-Candida activity at the concentration of 2.5 and 10\%. Staphylococcus aureus and Candida albicans were resistant to 2.5 and $5 \%$ water extracts, whereas Candida albicans was also resistant to 5\% methanolic extract[20].

Lepidium sativum seed oil extracted by soxhlet and maceration was evaluate against Escherichia coli, Klebsiella pneumonia, Acinetobacter baumannii, Pseudomonas aureginosa, Staphylococcus aureus, Bacillus subtilis, Candida albicans and Aspergillus flavus. Lepidium sativum seed oil extracted by maceration was partially active against Escherichia coli at concentrations of 10 and $50 \mu \mathrm{g} / \mathrm{ml}$, while the oil extracted by soxhlet showed no activity at these concentrations. At $50 \mu \mathrm{g} / \mathrm{ml}$ both samples were partially active against Klebsiella pneumonia. The soxhlet sample also exhibited partial activity against Bacillus subtilis at a concentration of 10 and $50 \mu \mathrm{g} / \mathrm{ml}$, while the macerated sample was inactive at these concentrations. Both samples were inactive against Staphylococcus aureus [34].

Methanol and ethyl acetate extract of the seeds of Lepidium sativum showed significant antibacterial activity against Rhodococcus equi [27].

The methanolic extract of Lepidium sativum seed was studied at different concentrations $(10,30,60$ and $90 \mathrm{mg} / \mathrm{ml}$ ) against human pathogenic and opportunistic fungi (Aspergillus flavus, Aspergillus fumigatus, Candida albicans, Fusarium sp, Penicillium sp and Penicillium marneffi). The Aspergillus flavus was the most sensitive fungi, it inhibited at $30 \mathrm{mg} / \mathrm{ml}$. Rhizopus $s p$. showed slow and weak growth on $30 \mathrm{mg} / \mathrm{ml}$ and $60 \mathrm{mg} / \mathrm{ml}$ slant and was completely inhibited at $90 \mathrm{mg} / \mathrm{ml}$. At a concentration of $90 \mathrm{mg} / \mathrm{ml}$, Aspergillus fumigatus, Candida albicans, Fusarium sp, Microsporum sp, Penicillium sp, Penicillium marneffi were completely inhibited [47].

The antifungal activity of ethanolic extract of Lepidium sativum seeds (2-8 mg) was evaluated against Fusarium equiseta, Aspergillus flavus and Alternaria alternate. The diameter of the inhibition zone ranged from 4 to $22 \mathrm{~mm}$ against the tested fungi [18].

\section{Hypoglycemic effects}

The hypoglycemic effect of the aqueous extract of Lepidium sativum seeds $(20 \mathrm{mg} / \mathrm{kg}$, orally for $16 \mathrm{~d})$ was investigated in normal and streptozotocin-induced diabetic rats. Administration of the aqueous extract of Lepidium sativum seeds caused a significant reduction in glucose, creatinine, and alkaline phosphatase levels. Elevated cholesterol level was restored approximately to normal and a significant decrease in malondialdehyde levels was also observed compared to diabetic controls [47].

The hypoglycemic activity of the methanol extract (three concentrations for four weeks) of Lepidium sativum seeds was tested 
in alloxan-induced diabetic male rats. Treating of diabetic rats with Lepidium sativum methanol extract decreased blood sugar and restored all biochemical and histological changes to the normal [48].

The antidiabetic effect of Lepidium sativum seed alkaloid $(50,150$ and $250 \mathrm{mg} / \mathrm{kg}$, ip for $21 \mathrm{~d}$ ) was studied in alloxan-induced diabetic rats. Lepidium sativum seed total alkaloid at $250 \mathrm{mg} / \mathrm{kg}$ showed $1.94 \%$ body weight gain on $21^{\text {th }}$ day relative to 6.14 and $8.94 \%$ of control and diabetic group. Lepidium sativum seed total alkaloid at the same dose significantly $(\mathrm{p}<0.001)$ suppressed blood glucose, cholesterol, triglyceride and urea level in diabetic rats [49].

The hypoglycaemic effect of an aqueous extract of Lepidium sativum seeds was investigated in normal and streptozotocin-induced diabetic rats. After a acute (single dose, $20 \mathrm{mg} / \mathrm{kg}$ ) or chronic $(20$ $\mathrm{mg} / \mathrm{kg}, \quad 15$ daily repeated administration) orally, the extract significantly decreased blood glucose levels in STZ diabetic rats $(\mathrm{p}<0.001)$; and normalised the blood glucose levels after $2 \mathrm{w}$ daily oral administration of the extract $(\mathrm{p}<0.001)$. A significant reduction on blood glucose levels was noticed in normal rats after both acute $(\mathrm{p}<0.01)$ and chronic treatment $(\mathrm{p}<0.001)[50]$.

The mechanism underlying the hypoglycaemic activity of the aqueous extract perfusion of Lepidium sativum was studied in normal and streptozotocin-induced diabetic rats. The aqueous extract at a dose of $10 \mathrm{mg} / \mathrm{kg} / \mathrm{h}$ reduced blood glucose levels and increased glycosuria in normal $(p<0.001)$ and diabetic rats $(p<0.001)$. Oral administration of aqueous extract for $15 \mathrm{~d}$ normalized glycaemia $(\mathrm{p}<0.001)$, enhanced glycosuria $(\mathrm{p}<0.05)$ and decreased the amount of urinary TGF-beta1 $(\mathrm{p}<0.01)$ in diabetic rats [51].

\section{Reproductive effects}

The effect of tocopherol extracted from Lepidium sativum seeds on the fertility was studied in the adult male rabbit. The results showed a significant increase $(\mathrm{p}<0.05)$ in testicular sperm concentration, epididymus sperm concentration and in the sperm count per gm of the testis, sperm motility percent, grade activity, sperm viability percent, with a decrease in abnormal sperm morphology percent [52].

The possible protective effects of Lepidium sativum seed extract (200 and $400 \mathrm{mg} / \mathrm{kg}$, orally) on fasting blood sugar and on the histopathological change of epididymis were studied in streptozotocin-induced diabetic rats. Administration of 200 and 400 $\mathrm{mg} / \mathrm{ml}$ doses of Lepidium sativum seed extract increased epithelium height and decreased interstitial volume density and fibromuscular thickness significantly. Tubular and lumen diameter did not change significantly in different groups [53].

The effect of Lepidium sativum seed ethanol extract (200 and 400 $\mathrm{mg} / \mathrm{kg}$, orally) on fasting blood sugar and its protective effect on histopathological changes in the ventral prostate gland were studied in streptozotocine-induced diabetic rats. Administration of the 200 and $400 \mathrm{mg} / \mathrm{kg}$ doses of Lepidium sativum seed extract increased epithelium height and decreased interstitial volume density and fibromuscular thickness of the prostate significantly [54].

The effect of Lepidium sativum aqueous extract on the fertility criteria in males was studied in mice. The aqueous extract was given alone for $2 \mathrm{w}$, or after sulpiride for $6 \mathrm{w}$ and then with the aqueous extract for $2 \mathrm{w}$. The results showed that the weight does not change over the first three weeks, but there was a significant increase in body weight at the fourth week. The group treated with both, sulpiride and Lepidium sativum aqueous extract showed the higher level of $\mathrm{LH}$, while the group which was treated with Lepidium sativum aqueous extract only showed a higher level of FSH. Prolactin showed its lowest level in the group treated only with Lepidium sativum aqueous extract. Testosterone showed a higher level in the group treated only with Lepidium sativum aqueous extract. Histological sections for the testes in the group treated with Lepidium sativum aqueous extract only showed normal appearance of seminiferous tubule with presence of high number of sperms, sulpiride hyperprolactinemic mice testis showed partial degeneration and damage of dispersed spermatogonia cells with still presence of sperms inside the lumen with certain morphological abnormality in the shape of the sperms. Sections of treated mice testis showed a look like normal shape and structure of seminiferous tubules with the presence of normal morphology shape sperms in the lumen [55].

However, the effects of aqueous extract of Lepidium sativum seed on the development and magnitude of surge releases of GnRH, LH, FSH, testosterone secretion and spermatogenesis were studied in rat. Rats that received Lepidium sativum extract showed no changes in hormonal status and reproductive organs histology. The author concluded that there was no conclusive data for the aphrodisiac claims. There is a paucity of information on of Lepidium sativum seed effects on female reproductive function. Lepidium sativum seed has been shown in females to act as a galactagogue, abortifacient and contraceptive [56].

The effect of methanolic extract ( 200 and $400 \mathrm{mg} / \mathrm{kg}$ for $21 \mathrm{~d}$ ) of seeds of Lepidium sativum was studied on proceptive and receptive behaviors of ovariectomized female Wistar rats. On $11^{\text {th }}$ and $21^{\text {st }}$ day, each female was tested in estrous phase for their sexual behavior in the copulatory test. Behavioral estrus was induced by subcutaneous administration of $25 \mu \mathrm{g}$ estradiol benzoate $48 \mathrm{~h}$ prior to behavioral testing and $500 \mu \mathrm{g}$ of progesterone $5 \mathrm{~h}$ before testing. As a measure of proceptivity, the number of hops, darts, ear wiggling and solicitations made by methanolic extract treated female rats were significantly increased when compared against control estrous females. Lordosis quotient, as a measure of receptivity, was unaffected by doses of methanolic extract [57].

However, the effects of dietary supplementation of Lepidium sativum seed powder $(0 \%, 5 \%, 7 \%$ and $10 \% \mathrm{w} / \mathrm{w})$ on growth performance and gonadotropins secretion were studied in ovariectomized, estradiol implanted rabbits. Feed intake was significantly $(\mathrm{p}<0.05)$ increased in Lepidium sativum seed powder supplemented group, but its didn't increase body weight gain. Lepidium sativum seed powder supplementation significantly $(\mathrm{p}<0.001)$ increased mean plasma LH, dose-dependently from the low-to the mid-Lepidium sativum seed powder level and then decreased LH at the highLepidium sativum seed powder level. Lepidium sativum seed powder supplementation increased $(\mathrm{p}<0.001)$ plasma FSH secretion [58].

\section{Gastrointestinal effects}

The aqueous-methanolic extract of Lepidium sativum seeds 30 and $100 \mathrm{mg} / \mathrm{kg}$ possessed atropine-sensitive prokinetic and laxative activities in mice, which were partially sensitive to atropine. In isolated gut preparations of mouse and guinea-pig, aqueousmethanolic extract $(0.1-1 \mathrm{mg} / \mathrm{ml})$ caused a concentration-dependent stimulatory effects both in jejunum and ileum, which was blocked by atropine. In rabbit jejunum, the stimulant effect of aqueousmethanolic extract remained unchanged in the presence of atropine, pyrilamine or SB203186, while in rabbit ileum, the stimulatory effect was partially blocked by atropine. The aqueousmethanolic extract was more efficacious in gut preparations of a rabbit than in guinea-pig or mouse. The phytochemical analysis of the plant extract revealed that it consisted of alkaloids [59].

The antidiarrheal activity of the methanolic extract of Lepidium sativum was investigated in three experimentally induced diarrhea models (castor oil-induced diarrhea; prostaglandin $\mathrm{E}_{2}$ induced enteropooling in rats and charcoal meal test in mice). In castor oil induced model, the methanolic extract (50, 100 and $200 \mathrm{mg} / \mathrm{kg}$, po) showed the significant dose-dependent reduction of cumulative wet fecal mass. In PG- $\mathrm{E}_{2}$ induced enteropooling model, the methanolic extract (50, 100 and $200 \mathrm{mg} / \mathrm{Kg}$, po) inhibited $\mathrm{PG}-\mathrm{E}_{2}$ induced secretions. In charcoal meal test, the methanolic extract (50, 100 and $200 \mathrm{mg} / \mathrm{kg}$, po) decreased the movement of charcoal, indicating its antimotility activity [60].

The seed extract of Lepidium sativum at 100 and $896 \mathrm{~kg}$ inhibited castor oil-induced diarrhea in rats. In isolated rat ileum, the seed extract $(0.01-5 \mathrm{mg} / \mathrm{ml})$ reversed carbachol $(1 \mu \mathrm{M})$ and $\mathrm{K}+$ $(80 \mathrm{mM})$-induced contractions with higher potency against carbachol. Preincubation of rat ileum with a lower concentration of seed extract $(0.03 \mathrm{mg} / \mathrm{ml})$ caused a rightward parallel shift in the concentration-response curves of carbachol without suppression of the maximum response, while at the next higher concentration $(0.1 \mathrm{mg} / \mathrm{ml})$, it produced a non-parallel rightward shift with suppression of the maximum response. The seed extract shifted the 
concentration-response curves of $\mathrm{Ca}^{++}$to the right with suppression of the maximum response. Accordingly, Lepidium sativum seed extract possessed antidiarrheal and spasmolytic activities mediated through dual blockade of muscarinic receptors and $\mathrm{Ca}^{++}$channels [61].

The antidiarrheal and antispasmodic activities of the crude extract of Lepidium sativum were further studied using in vivo and in vitro experiments. The crude extract inhibited castor oilinduced diarrhea in mice at 300 and $1000 \mathrm{mg} / \mathrm{kg}$ (three times higher dose than for rats). In isolated rat ileum and jejunum, crude extract completely inhibited carbachol, low $\mathrm{K}^{*}(25 \mathrm{mmol})$ and high $\mathrm{K}^{*}(80$ mmol)-induced contractions while in Guinea-pig tissues, crude extract caused complete inhibition of only carbachol-induced contraction. In rabbit tissues, crude extract completely inhibited carbachol and low $\mathrm{K}^{*}$-induced contractions sensitive to $\mathrm{K}^{\star}$ channel antagonists. Pretreatment of Guinea-pig and rat tissues with crude extract caused a rightward shift in carbachol-induced contractions, while in rabbit and rat tissues, crude extract shifted isoprenaline curves. The results indicated that the antidiarrheal and antispasmodic activities of Lepidium sativum mediated through activation of $\mathrm{K}^{+}$channels, and inhibition of muscarinic receptors, $\mathrm{Ca}^{++}$channels and PDE enzyme [62].

Clinical isolates of H. pylori were tested in vitro for susceptibility to ethanol extract of Lepidium sativum. The ethanol extract exerted antibacterial activity against $H$. pylori isolates. MIC value was $15-29$ $\mathrm{mm}$ for concentrations of 100000,50000 and $25000 \mu \mathrm{g} / \mathrm{ml}$ respectively [63].

\section{Respiratory effects}

The ethanolic extract of seeds of Lepidium sativum and its fractions (ethyl acetate, n-butanol and methanol) were tested for bronchodilatory effect against histamine and acetylcholine-induced acute bronchospasm in Guinea pigs. The ethanolic extract and its fractions exhibited significant protection against bronchospasm induced by histamine and acetylcholine, while, n-butanol fraction induced significant $(\mathrm{p}<0.001)$ protection comparable to ketotifen $(1$ $\mathrm{mg} / \mathrm{kg})$ and atropine sulphate $(2 \mathrm{mg} / \mathrm{kg}$ [64].

The anti-asthmatic effect of Lepidium sativum seed powder (1 gm thrice a day orally) was investigated in patients of mild to moderate bronchial asthma. The respiratory functions (FVC, FEV1, FEF25-75\% and MVV) were assessed using a spirometer prior to, and after $4 \mathrm{w}$ of treatment. Efficacy of the drug in improving clinical symptoms and severity of asthmatic attacks was evaluated by interviewing the patient and by physical and hematological examination at the end of the treatment. Four weeks of treatment with the drug showed significant improvement in pulmonary functions and in clinical symptoms and severity of asthmatic attacks. None of the patients showed any adverse effect with Lepidium sativum [65].

The crude extract of Lepidium sativum inhibited carbachol $(1 \mu \mathrm{M})$ and $\mathrm{K}^{+}(80 \mathrm{mmol})$ induced contractions in Guinea pig tracheal ring strips, in a pattern similar to that of dicyclomine. The crude extract at $0.03 \mathrm{mg} / \mathrm{ml}$ produced a rightward parallel shift of carbachol curves, followed by a nonparallel shift at higher concentration $(0.1$ $\mathrm{mg} / \mathrm{ml}$ ), suppressing maximum response, similar to that caused by dicyclomine. Pretreatment of tissues with crude extract (0.1-0.3 $\mathrm{mg} / \mathrm{ml}$ ) shifted $\mathrm{Ca}^{++}$concentration-response curves to right, as produced by verapamil. The crude extract at low concentrations $(0.03-0.1 \mathrm{mg} / \mathrm{ml})$ caused a leftward shift of isoprenaline-induced inhibitory $\mathrm{Ca}^{++}$concentration-response curves, like that caused by rolipram, a phosphodiesterase inhibitor. Accordingly, the results indicated that the bronchodilatory effect of Lepidium sativum was mediated by anticholinergic, $\mathrm{Ca}^{++}$antagonist and phosphodiesterase inhibitory pathways [66].

\section{Anti-inflammatory, analgesic and antipyretic effects}

The activities of the optimized LSP extract of Lepidium sativum were tested in an in vivo endotoxin shock induced in mice with a single $E$. coli ip injection. Septic mice showed a substantial raise in the levels of TNF- $\alpha$ in plasma, whereas mice treated with Lepidium sativum polysaccharides (LSP) after $E$. coli injection showed considerable lower plasma levels of TNF- $\alpha(p<0.05)$, which indicated the beneficial effects of LSP when administered to mice with endotoxin shock by diminishing the pro-inflammatory response [67].

Modulatory effects on lipid composition, spleen lymphocyte proliferation and inflammatory mediators (such as nitric oxide and leukotriene B4) were possessed by $\alpha$-linolenic acid-rich Lepidium sativum seed oil $(2.5,5$ and $10 \%, \mathrm{w} / \mathrm{w}$, for $8 \mathrm{w})$ in rats [68].

Denaturation of tissue proteins is one of the well-documented causes of inflammatory and arthritis diseases. The protein denaturation bioassay was used for in vitro assessment of the anti-inflammatory property of methanol extract of Lepidium sativum seeds. the methanol extract of Lepidium sativum seeds exhibited a concentrationdependent inhibition of protein (albumin) denaturation throughout the concentration range from 25 to $1000 \mu \mathrm{g} / \mathrm{ml}$ [69].

The ethanolic extract of Lepidium sativum seeds was studied for antiinflammatory, antipyretic, and analgesic activities. The extract significantly inhibited carrageenan-induced paw edema in rats. It also significantly inhibited the yeast-induced hyperpyrexia in mice. The mean predrug rectal temperature in yeast-induced fevered mice was $37.13 \pm 0.05{ }^{\circ} \mathrm{C}$. The administration of extract reduced the temperature to $36.86 \pm 0.04,36.68 \pm 0.05$ and $36.53 \pm 0.07{ }^{\circ} \mathrm{C}$ at 30,90 and $150 \mathrm{~min}$ following the treatment respectively. Administration of Lepidium sativum extract $(500 \mathrm{mg} / \mathrm{kg})$ also significantly prolonged the hot plate reaction time. The ethanolic extract of Lepidium sativum seeds which possed anti-inflammatory, antipyretic and analgesic activities also exacerbated indomethacin-induced gastric mucosal damage. The coagulation studies showed a significant increase in fibrinogen level and an insignificant decrease in prothrombin time, confirming its coagulating property [15].

The antinociceptive effect of the aqueous extract of Lepidium sativum $(20 \mathrm{mg} / \mathrm{kg}$ orally) was investigated using acetic acidinduced writhing test and hot plate test in mice. The aqueous extract showed significantly $(\mathrm{p}<0.05)$ analgesic activity evidenced by an increase in the reaction time by hot plate method and significant $(p<0.05)$ reduction in acetic acid-induced writhings in mice with a maximum effect of $27 \%$ reduction [70].

In a clinical trial, the seeds ( 6 gm divided in two doses daily, orally) were evaluated for the management of osteoarthritis. The patients were subjected to the evaluation of cardinal sign and symptoms on the basis of scores according to their severity, frequency and duration before and after treatment. Seeds showed considerable improvements in cardinal signs and symptoms like pain in joints, swelling, stiffness, crepitus, tenderness and difficulty in movement (30\% complete remission, $37.5 \%$ marked improvement, $25 \%$ moderate improvement, and only 7.5\% didn't improve)[71].

\section{Cardiovasular and diuretic effect}

The ethanolic extract of the seeds of Lepidium sativum $(10-20 \mathrm{mg} / \mathrm{kg}$, iv) caused marked rise in blood pressure of anesthetized cats and dogs, with slight transient (0.5-1 min) respiratory stimulation. The extract was not potentiated or depress the pressor responses of adrenaline and carotid occlusion. The extract caused marked increase in the rate and force of auricular and ventricular movements of open chest cat heart preparation. The cardiac stimulatory effect was also observed on isolated rabbit auricles [72, 73].

The antihypertensive effect of the aqueous extract of Lepidium sativum was studied in normotensive and spontaneously hypertensive rats. Daily oral administration of the aqueous extract $(20 \mathrm{mg} / \mathrm{kg}$ for $3 \mathrm{w})$ caused a significant decrease in blood pressure $(p<0.01)$ in hypertensive rats, with no significant change in normotensive rats during the period of treatment. The systolic blood pressure was decreased significantly from the $7^{\text {th }}$ day $(\mathrm{p}<0.05)$ to the end of treatment $(\mathrm{p}<0.01)$ in hypertensive rats. No significant changes were recorded on heart rate after the aqueous extract treatment in hypertensive and normotensive rats. The diuretic effect of the aqueous extract of Lepidium sativum was studied in normotensive and spontaneously hypertensive rats. The aqueous extract enhanced significantly the water excretion in normotensive rats $(p<0.001)$ but not in hypertensive rats. Furthermore, oral administration of the aqueous extract at a dose of $20 \mathrm{mg} / \mathrm{kg}$ produced significant increase of urinary excretion of sodium 
$(\mathrm{p}<0.05)$, potassium $(\mathrm{p}<0.01)$ and chlorides $(\mathrm{p}<0.01)$ in normotensive rats. In spontaneously hypertensive rats, the aqueous extract administration induced significant increase of urinary elimination of sodium $(\mathrm{p}<0.01)$, potassium $(\mathrm{p}<0.001)$ and chlorides $(\mathrm{p}<0.001)$. Glomerular filtration rate showed a significant increase after oral administration of the aqueous extract in normal rats $(p<0.001)$, while in hypertensive rats, no significant change was noted during the period of treatment [74].

The diuretic effect of aqueous and methanol extracts of the dried seeds of Lepidium sativum (orally, 50 and $100 \mathrm{mg} / \mathrm{kg}$ ) was investigated in normal rats. Urine volume and the excretion of sodium were significantly increased by the two doses of aqueous and methanol extracts, while, potassium excretion was only increased by the aqueous extract at a dose of $100 \mathrm{mg} / \mathrm{kg}$. The extracts caused no significant change in the conductivity and $\mathrm{pH}$ of urine [75].

\section{Antioxidant activity}

The antioxidant content and activity of the methanol extract of Lepidium sativum subsp spinescens was investigated in vitro. The extract contained high amounts of phenolic and flavonoid compounds and showed significant antioxidant activity [76].

The antioxidative effects of the ethanolic extract of Lepidium sativum shoot, leaf and stem were studied against DPPH, total glutathione Stransferase assay, reduced glutathione activity, reducing power $\left(\mathrm{Fe}^{3+}-\mathrm{Fe}^{2+}\right.$ transformation ability). High scavenging activity was noted in the shoot $(12.19 \pm 02 \%)$ and least in stem $(2.69 \pm 05 \%)$. The activity of the total glutathione S-transferase enzyme was more in seed $(9600 \pm 56.3 \mu \mathrm{g} / \mathrm{ml})$ than other plant parts. The reduced glutathione content of the ethanolic extracts of Lepidium sativum was more in leaf $(9 \pm 0.2 \mu \mathrm{g} / \mathrm{ml})$. In the reducing power assay, ethanolic extracts showed the most potent reducing ability [77].

The ethanol extract showed concentration-dependent antioxidant activity ( 0.146 to $18.75 \mathrm{mg} / \mathrm{ml}$ ), the methanol extract was found to be a strong reducing agent and hence a strong antioxidant. Petroleum ether extract caused concentration-dependent antioxidant activity. The maximum increase in antioxidant activity was observed on changing the concentration from $3.125 \mathrm{mg} / \mathrm{ml}$ to $6.25 \mathrm{mg} / \mathrm{ml}$ [78].

Methanol and ethyl acetate extract of the seeds of Lepidium sativum showed significant antioxidant activity. Methanol extract exhibited antioxidant activities with IC 50 of $925.22 \pm 0.02 \mathrm{ppm}[27]$.

The seeds extract possessed good ferric reducing antioxidant power and DPPH radical scavenging activity with IC[50]:176.18 $\mu \mathrm{g} / \mathrm{ml}$. The antioxidant activity was also correlated to the total phenolic content of the seeds[79].

Phenolics identified in the ethanolic extract of Lepidium sativum (kaempferol, coumaroylquinic acid, $p$-coumaroyl glycolic acid and caffeic acid), showed significant antioxidant activity with IC $_{50}$ values of $162.4 \pm 2.3,35.29 \pm 1.02,187.12 \pm 3.4$ and $119.32 \pm 1.5 \mu \mathrm{g} / \mathrm{ml}$ in terms of DPPH, ABTS, superoxide scavenging activity and metal chelating property respectively. Further, the ethanol extract showed $\mathrm{IC}_{50}$ values of $73.72 \pm 1.23$ and $121.78 \pm 1.03 \mu \mathrm{g} / \mathrm{ml}$ in HRBC membrane stabilization ability and protein denaturation inhibition capacity respectively [37].

\section{Anticancer effects}

Cytotoxic effects of the plant extract on colon and endometrium cancer cells, in addition to human peripheral lymphocyte cells, were investigated in vitro by MTT and neutral red assays. Furthermore, the plant extract was investigated for necrotic effects by LDH assay; apoptotic activity by DNA ladder fragmentation, ELISA and acridine orange/ethidium bromide staining; and genotoxic effect by comet assay methods. The extract showed significant cytotoxic activity on colon and endometrium cancer cells in a concentration-dependent manner. Apoptotic activity and genotoxic effects were significantly increased, especially with $200 \mu \mathrm{g} / \mathrm{ml}$ concentrations at $48 \mathrm{~h}$ incubation [76].

The cytotoxic effects of hydro-alcoholic extracts of Lepidium sativum shoots (before and after flowering) were studied in K562 cell line as a model of chronic myeloid leukemia. The hydro-alcoholic extracts of Lepidium sativum prepared before and after flowering exhibited a dose and time-dependent cytotoxic effect on K562 cell line [80].

The cytotoxic activity of $n$-hexane, chloroform, ethyl acetate and methanol seeds extracts of Lepidium sativum was studied against human cancer cell lines such as human neuroblastoma cell line (IMR-32), colon cancer cell lines (HT-15 and HT-29) and lung cancer cell line A-549. The methanolic extract of Lepidium sativum exhibited a very high in vitro cytotoxic activity than that of standard mitomycin-C. Other three extracts showed no cytotoxicity [81].

The anticancer activity of Lepidium sativum seeds was investigated against HEp2 cells (human laryngeal carcinoma cells). The highest cytotoxic activity for the acetate ethyl extract (rich with 0glycosides) at $57 \mu \mathrm{g} / \mathrm{ml}$ was recorded against HEp2 cells, cells proliferation were reduced $87 \%$, this effect could be attributed to the apoptosis effects of the extract [82].

The ability of the extract to induce apoptosis and necrosis was investigated in the human breast cancer cell line MCF-7, compared to normal human skin fibroblasts. Apoptosis can be induced in both cells, by treatment with $25 \%$ and $50 \%$ extract, while necrosis was observed mainly after exposure to elevated extract concentrations $(75 \%)$. DNA fragmentation was noted in both cells, in a time and dose-dependent manner. Both cells, at all extract concentrations, showed no significant differences in the number of living, dead, apoptotic, and necrotic cells [83].

\section{The protective effects}

The hepatoprotective effect of the Lepidium sativum ethanolic extract $(150$ and $300 \mathrm{mg} / \mathrm{kg})$ was assessed by Dgalactosamine-induced/lipopolysaccharide liver damage model in rats. The extract possessed marked amelioration of hepatic injuries by attenuation of serum and lipid peroxidation. The extract also significantly down-regulated the D-GalN/IPS induced proinflammatory cytokines TNF $\alpha$ and IL-6 mRNA expression in a dosedependent fashion and up-regulated the IL-10. It also possessed hepatoprotective activity by down-regulating mRNA expression of iNOS and $\mathrm{HO}^{-1}$. MPO activity and NF-KB DNA-binding effect were mitigated by the extract dose-dependently [84].

The hepatoprotective effect of ethanolic extract of Lepidium sativum seed $(100,200$, and $400 \mathrm{mg} / \mathrm{kg}$, once daily for 7 consecutive days) was studied against carbon tetrachloride-induced acute liver injury in rats. Pretreatment with the ethanolic seeds extracts significantly reduced the level of serum alanine transaminase, aspartate transaminase, alkaline phosphatase and bilirubin, which was increased significantly in carbon tetrachloride intoxicated group. Histological analysis of liver tissues in groups pretreated with the ethanolic seeds extracts showed mild necrosis and inflammation of the hepatocytes compared to the intoxicated group [85].

Three isoflavonoids (5,6-dimethoxy-2',3'-methylenedioxy-7-C- $\beta$-dgluco-pyranosyl isoflavone, 7-hydroxy-4',5,6-trimethoxyisoflavone and 7-hydroxy-5,6-dimethoxy-2',3'-methylenedioxyisoflavone) isolated from Lepidium sativum were evaluated for their ability to reduce the hepatotoxicity induced by paracetamol in male rats. Isoflavonoids possessed hepatoprotective effects by reducing the damage and toxicity with a significant improvement of total antioxidant capacity and normalizing the levels of liver enzymes GSH, SOD, GPX, CAT and GST compared to control group [39].

The hepatoprotective effect of methanolic extract (200 and 400 $\mathrm{mg} / \mathrm{kg}$ ) of Lepidium sativum was investigated in $\mathrm{CCl}_{4}$ induced liver damage in rats. The extract caused significant reduction in biochemical parameters of the treated group. The severe fatty changes in the livers of untreated rats were significantly decreased in the extract-treated group [86].

The protective effects of chloroform extract of Lepidium sativum seed were investigated against oxidative stress and cytotoxicity induced by hydrogen peroxide $\left(\mathrm{H}_{2} \mathrm{O}_{2}\right)$ in human liver cells (HepG2). Pre-exposure to the chloroform extract significantly attenuated the loss of cell viability up to $48 \%$ at $125 / \mathrm{ml}$ concentration against $\mathrm{H}_{2} \mathrm{O}_{2} \quad$ (LD50 value $=2.5 \mathrm{mM}$ ). The results also showed that the 
chloroform extract at $25 \mu \mathrm{g} / \mathrm{ml}$ concentration significantly inhibited the induction of reactive oxygen species generation (45\%) and lipid peroxidation $(56 \%)$, and increases the mitochondrial membrane potential (55\%) and reduced glutathione levels (46\%) [87].

The effects of aqueous extract of Lepidium sativum (200 and 400 $\mathrm{mg} / \mathrm{kg}$, po) against nephrotoxicity induced by doxorubicin was investigated in rats. The serum urea and creatinine levels in the doxorubicin treated group was significantly elevated $(\mathrm{P}<0.001)$, while it was significantly reduced in the Lepidium saivum aqueous extract treated groups. The renal antioxidant enzymes such as superoxide dismutase, catalase activities and level of reduced glutathione were declined and the level of malondialdehyde was elevated in the doxorubicin treated group. The activities of superoxide dismutase, catalase and level of reduced glutathione were elevated and level of malondialdehyde declined significantly in the Lepidium sativum plus doxorubicin. Histopathologically, Lepidium sativum markedly ameliorated doxorubicin-induced renal tubular necrosis [88].

The nephrocurative and nephroprotective activity of $200 \mathrm{mg} / \mathrm{kg}$ ethanolic extract of Lepidium sativum seed was investigated against cisplatin-induced nephrotoxicity. A single dose of cisplatin-induced loss in body weight, increase urine excretion and increased serum urea and creatinine. These effects were significantly recovered by $200 \mathrm{mg} / \mathrm{kg}$ in curative and protective groups. The malondialdehyde, superoxide dismutase, catalase and reduced glutathione level, were significantly elevated by $200 \mathrm{mg} / \mathrm{kg}$ in curative and protective groups. The level of brush border enzymes like $\mathrm{Na}^{+} / \mathrm{K}^{+} A T P a s e$, $\mathrm{Ca}^{++} \mathrm{ATPase}$ and $\mathrm{Mg}^{++} \mathrm{ATPase}$ were significantly reduced after singledose cisplatin injection and significantly elevated by treatment in curative and protective groups [89].

The protective effect of $5 \%$ and $10 \%$ of Lepidium sativum seeds powder was studied in acute renal failure in male albino rats. The results showed that feeding acute renal failure with seeds powder at $5 \%$ and $10 \%$ in curative and protective groups improved the body weight gain, feed intake and feed efficiency ratio. The diet fortified at $5 \%$ and $10 \%$ seeds powder helped to improve blood lipid levels as well as reducing hazards on kidney and liver function compared with positive control groups (injected with cisplatin, which were considered as a major risk factor for renal failure disease). Histopathologically, kidney of rats in curative and protective groups fed on basal diet containing seeds powder at $10 \%$ showed mild proximal tubules cell necrosis and minimal interstitial inflammation [90].

The chemoprotective effect of Lepidium sativum and its constituents, glucotropaeolin and benzylisothiocyanate (a breakdown product of Lepidium sativum), towards 2-amino-3-methyl-imidazo [4,5-f] quinoline-induced genotoxic effects and colonic preneoplastic lesions was investigated in single cell gel electrophoresis (SCGE) assays and in aberrant crypt foci (ACF) experiments. Pretreatment of F344 rats with either fresh Lepidium sativum juice $(0.8 \mathrm{ml})$, glucotropaeolin $(150$ $\mathrm{mg} / \mathrm{kg}$ ) or benzylisothiocyanate $(70 \mathrm{mg} / \mathrm{kg})$ for three consecutive days caused significant $(\mathrm{p}<0.05)$ reduction in 2 -amino-3-methylimidazo [4,5-f] quinoline ( $90 \mathrm{mg} / \mathrm{kg}, 0.2 \mathrm{ml}$ corn oil/animal)-induced DNA damage in colon and liver cells in the range of 75-92\%. Chemical analysis of Lepidium sativum juice showed that benzyl isothiocyanate didn't account for the effects of the juice, as its concentration in the juice was found to be 1000 -fold lower than the dose required to cause a chemoprotective effect. Lepidium sativum juice and benzylisothiocyanate did not affect the activity of cytochrome P4501A2, glutathione-S-transferase significantly, Lepidium sativum juice caused significant $(\mathrm{p}<0.05)$ increase in the activity of hepatic UDPGT-2. In the aberrant crypt foci assay, 2-amino-3-methyl-imidazo [4,5-f] quinoline was administered by gavage on 10 alternating days in corn oil (dose $100 \mathrm{mg} / \mathrm{kg}$ ). Five days before and during 2-amino-3methyl-imidazo [4,5-f] quinoline treatment, subgroups received drinking water which contained $5 \%$ Lepidium sativum juice. The total number of 2-amino-3-methyl-imidazo [4,5-f] quinoline-induced aberrant crypts and ACF as well as ACF with crypt multiplicity of >or $=4$ were reduced significantly $(\mathrm{p}<0.05)$ in the group that received 2 amino-3-methyl-imidazo [4,5-f] quinoline plus Lepidium sativum juice compared with the group that was fed with 2-amino-3-methyl-imidazo [4,5-f] quinoline only [91].

\section{CNS activity}

The effect of total alkaloid from seeds of Lepidium sativum (50, 150 and $250 \mathrm{mg} / \mathrm{kg}$, ip) on thiopental induced hypnosis (mice), locomotor activity (mice), motor coordination (mice), antianxiety (mice) and analgesic effect (rats) were investigated. The results revealed that the total alkaloid from seeds of Lepidium sativum considerably potentiated the thiopental induced hypnosis, decreased locomotor activity and motor coordination, and increased preference to plus-maze open arm. The total alkaloid from seeds of Lepidium sativum also increased the reaction time in caudal immersion and decreased the number of wriths in acetic acid-induced writhing [92].

\section{Hypolipidemic effects}

The total cholesterol, triacylglycerol and alanine transaminase (ALT) activity were increased significantly in the rats fed with high cholesterol diet as compared to the control group. Lepidium sativum reduced total cholesterol and ALT; however, higher dose $(6 \mathrm{~g} / \mathrm{kg}$ diet) was found better than lower dose $(3 \mathrm{~g} / \mathrm{kg}$ diet $)$ in reducing serum triacylglycerol. Histopathological findings revealed that liver of cholesterol-treated rats showed varying degrees of vacuolar degeneration, fatty changes, fatty cysts, and lobular disarray. Livers of the Lepidium sativum-treated rats showed mild to moderate degree of recovery [93].

The effects of Lepidium sativum extract ( $20 \mathrm{mg} / \mathrm{kg}$, orally for $4 \mathrm{w}$ ) on the blood glucose and lipid profile were studied in hypercholesterolemic rats. Lepidium sativum treated group showed a significant lower value of plasma glucose $30 \%$, cholesterol $22 \%$, triglycerides 25\%, LDL 23\% and increase in HDL 32\% [94].

\section{Effect on fracture healing}

The effect of Lepidium sativum seeds on fracture healing was investigated in fractures induced in the midshaft of the left femur of adult New Zealand White rabbits. The rabbits were fed soon after surgery with Lepidium sativum seeds mixed with their normal diet, whereas no seeds were given to the control group. X-rays of the induced fractures were taken at 6 and $12 \mathrm{w}$ postoperatively to assess the healing of the fractures; furthermore the callus formation in millimeters at the longitudinal medial, longitudinal lateral and circumferential areas were also investigated. The test group had a statistically significant increase in the healing of fractures compared with the control group $(\mathrm{p}<0.001$ for longitudinal medial $/ 6 \mathrm{w}, \mathrm{p}<0.004$ for circumferential, and $\mathrm{p}<0.043$ for longitudinal medial $/ 12 \mathrm{w}$ ) [95].

\section{Side effects and toxicity}

The administration of the ethanolic extract of Lepidium sativum seeds in single doses of 0.5 to $3.0 \mathrm{~g} / \mathrm{kg}$ did not produce any adverse effects or mortality in mice, whereas the animals treated with extract ( $100 \mathrm{mg} / \mathrm{kg} /$ day) for a period of 3 mo in drinking water showed no symptoms of toxicity except a statistically insignificant higher mortality rate [15].

The acute and subchronic toxicity of Lepidium sativum seeds was studied in adult Wistar rats. For the acute toxicity study, 0.5-5.0 $\mathrm{g} / \mathrm{kg}$ bw of the seed powder was administered through diet to rats, and obvious symptoms of toxicity and mortality were monitored for $72 \mathrm{~h}$. Acute doses of seed powder did not induce any symptoms of toxicity or mortality in rats. In subchronic toxicity study, 1.0-10.0\% of the seed powder was administered to rats through diet for $14 \mathrm{w}$. Dietary feeding of seed powder did not produce any mortality, no significant changes in food intake, gain in body weight, the relative weight of organs and hematological parameters, macroscopic and microscopic changes in vital organs, were observed between experimental and control groups. Enzymes (LDH and SGPT) were within normal levels; however, the serum ALP and SGOT were significantly increased in male rats receiving 5.0 and $10 \%$ of seed powder [96].

Lepidium sativum seed fed to Wistar albino rats at $2 \%(\mathrm{w} / \mathrm{w})$ was non-toxic, $10 \%(\mathrm{w} / \mathrm{w})$ was toxic but not fatal and $50 \%(\mathrm{w} / \mathrm{w})$ of the diet for $6 \mathrm{w}$ was lethal and caused depression in growth rate and entero-hepato-nephrotoxicity. Organ lesions were accompanied by anemia and leukopenia and were correlated with alterations in 
serum AST and ALT activities and concentrations of total protein, cholesterol, urea, and other serum constituents [97].

Water suspension of seed powder of Lepidium sativum $(2,4,8$ $\mathrm{g} / 100 / \mathrm{ml}$ ) in male rats for 3 and $6 \mathrm{w}$ increased total serum protein, albumin was increased at the high dose group, and AST and GGT were within normal levels. ALT and ALK were significantly increased after $3 \mathrm{w}$ in males receiving 2 and $4 \mathrm{~g} / \mathrm{kg}$, respectively. Liver parenchyma showed vascular dilation with congestion of central and portal veins in low doses ( 2 and $4 \mathrm{mg} / \mathrm{ml}$ ) for $3 \mathrm{w}$, high doses given for $3 \mathrm{w}$ showed periportal fibrosis and perivascular edema. Bile duct proliferation was a prominent feature in the specimens of Lepidium sativum treated animals [98].

The possible adverse effect of alcoholic extract of seeds of Lepidium sativum and Lepidium sativum seed oil on HepG2 cells, a human liver cell line was studied. Cells were exposed to 25 to $1000 \mu \mathrm{g} / \mathrm{ml}$ of alcoholic extract of seeds of Lepidium sativum and Lepidium sativum seed oil for $24 \mathrm{~h}$. The results show that the extracts reduced cell viability and altered the cellular morphology in dose-dependent manner. They were also induced oxidative stress in dose-dependent manner indicated by decrease in glutathione level, catalase activity, and SOD activity and an increase in lipid peroxidation [99].

In the study of the acute and chronic effects of 15\% of Lepidium sativum seed supplementation on gross organ morphology and histomorphometric indices in rats, it appeared that Lepidium sativum seed increased renal weight in the treated group. Histological analysis showed a significant change in the diameter of the Bowman's capsule, glomerulus and Bowman's space in the treated group. There was also an increase in glomerulosclerosis, metaplasia and hyperplasia in rats fed $15 \%$ of Lepidium sativum seed. In the proximal and distal tubules, there was a significant increase in tubular degeneration throughout the experiment. These results paired together show a significant toxic effect for rats fed $15 \%$ Lepidium sativum seed [56].

The effects of an aqueous Lepidium sativum seeds extract on the immune system and general health was studied in mice. An aqueous extract of ground Lepidium sativum seeds was orally gavaged to young adult male Swiss albino mice at a low dose $(0.5 \mathrm{ml})$ and a high dose (1 $\mathrm{ml}$ ) daily for 19-21 d. Results showed that Lepidium sativum seeds extract caused statistically significant increases in the mean white blood cell count and mean spleen weight in low dose group; however, for the high dose group, the increases tended to be more significant. The mean body weight for the high dose group showed clear increases compared to the control. The mean of white blood cell types, red blood cell, and platelet counts; mean hemoglobin concentration; mean total body gains; and weights of the organs (except for the spleen) were not significantly different for the low dose and high dose groups compared to the control [100].

One gram of Lepidium sativum seed powder/thrice a day for four weeks in asthmatic patients produced no adverse effect in all treated patients [65].

The oil extracted from the plant was edible and was used as a cooking medium, some people may experience symptoms of indigestion due to its use. However, consuming of large quantities of the plant caused digestive difficulties in some people. Furthermore, it contained goitrogens that prevent iodine absorption in thyroids and can lead to hypothyroidism. It should be avoided by patients of hypothyroidism.

It was an abortifacient; pregnant women should avoid taking the plant in any form because it induce uterine contractions and triggered spontaneous abortion [24-25].

\section{CONCLUSION}

The current review discussed the chemical constituents, pharmacological effects and therapeutic importance of Lepidium sativum as a promising medicinal plant with wide range of pharmacological activities which could be utilized in several medical applications because of its effectiveness and safety.

\section{ACKNOWLEDGMENT}

I acknowledged the dean of Thi qar college of medicine for his scientific support.

\section{AUTHORS CONTRIBUTIONS}

All the author have contributed equally

\section{CONFLICTS OF INTERESTS}

There is no conflicts of interest. I am, alone responsible for the content and writing of this article.

\section{REFERENCES}

1. Al-Snafi AE. Chemical constituents and pharmacological activities of milfoil (Achillea santolina)-a review. Int J Pharm Tech Res 2013;5:1373-7.

2. Al-Snafi AE. Pharmacological and therapeutic importance of Hibiscus sabdariffa-a review. Int J Pharm Res 2018;10:451-75.

3. Al-Snafi AE. The pharmaceutical importance of Althaea officinalis and Althaea rosea: a review. Int J Pharm Tech Res 2013;5:1387-5.

4. Al-Snafi AE. The pharmacology of Anchusa italica and Anchusa strigosa-a review. Int J Pharm Pharm Sci 2014;6:7-10.

5. Al-Snafi AE. The pharmacological importance of Anethum graveolens-a review. Int J Pharm Pharm Sci 2014;6:11-13.

6. Al-Snafi AE. Immunological effects of medicinal plants: a review (part 2). Immunol Endocr Metab Agents Med Chem 2016;16:100-21.

7. The plant list, Lepidium sativum. Available from: http://www.theplantlist.org/tpl1.1/record/kew-2338547 [Last accessed on 05 Jul 2019]

8. IT IS report, Lepidium sativum. Available from: https://www.itis.gov/servlet/SingleRpt/SingleRpt?search_topic=T SNandsearch_value=22978\#null. [Last accessed on 05 Jul 2019]

9. U. S. National Plant Germplasm System Lepidium sativum. Available from: https://npgsweb.ars-grin.gov/gringlobal/ taxonomydetail.aspx?21769. [Last accessed on 05 Jul 2019]

10. Wadhwa S, Panwar MS, Agarwal A, Saini N, Patidar LN. A review on pharmacognostical study of Lepidium sativum. Adv Res Pharm Biol 2012;2(IV):316-23.

11. Raval ND, Pandya TN. Pharmacognostic study of Lepidium sativum Linn. Int Quarterly J Res Ayurveda 2011;32:116-9.

12. Brotonegoro $\mathrm{S}$, Wiharti W. Lepidium sativum L. In: van Valkenburg, JLCH and Bunyapraphatsara N. (Eds). Plant Resources of SouthEast Asia No 12: Medicinal and poisonous plants 2. Backhuys Publishers, Leiden, Netherlands; 2001. p. 334-7.

13. Mukhopadhyay D, Parihar SS, Chauhan JS, Preeti, Joshi SC. Effect of temperature and desiccation on seed viability of Lepidium sativum L. New York Sci J 2010;3:34-6.

14. Datta PK, Diwakar BT, Viswanatha S, Murthy KN, Naidu KA. Safety evaluation studies on garden cress (Lepidium sativum L.) seeds in Wistar rats. Int J Appl Res Nat Prod 2011;4:37-43.

15. Al-Yahya M, Mossa J, Ageel A, Rafatullah S. Pharmacological and safety evaluation studies on Lepidium sativum L seeds. Phytomedicine 1994;1:155-9.

16. Chopra RN, Nayar SL, Chopra LC. Glossary of Indian medicinal plants. Council of Scientific and Industrial Research, New Delhi, India; 1986.

17. Ahsan SK, Tarig M, Ageel M, Alyanya MA, Shah AH. Studies on some herbaldrugs used in fracture healing. Int J Crude Drug Res 1989;27:235-9.

18. Sharma S, Agarwal N. Nourishing and healing prowess of garden cress (Lepidium sativum Linn). Indian J Nat Prod Res 2011;2:292-7.

19. Baytop T. Türkiye'de Bitkiler ile Tedavi. Nobel Tip Istanbul; 1999. p. 480-5.

20. Adam SIA, Salih SAM, Abdelgadir WS. In vitro antimicrobial assessment of Lepidium sativum L. seeds extracts. Asian J Med Sci 2011;3:261-6.

21. Mathews S, Singhal RS, Kulkarni PR. Some phsiochemical characteristics of Lepidium sativum seeds. Nahrung 1993;37:69-71.

22. Ahmad R, Mujeeb M, Anwar F, Husain A, Ahmad A, Sharma S. Pharmacognostical and phytochemical analysis of Lepidium sativum L seeds. Int Curr Pharm J 2015;4:442-6.

23. Gokavi SS, Malleshi NG, Guo M. Chemical composition of garden cress (Lepidium sativum) seeds and its fractions and use of bran as a functional ingredient. Plant Foods Human Nutr 2004;59:105-11. 
24. Singh CS, Paswan VK, Naik B, Reeta. Exploring the potential of fortification by garden cress (Lepidium sativum L) seeds for development of functional foods. Indian J Natl Prod Res 2015;6:167-75.

25. Singh CS, Paswan. The potential of garden cress (Lepidium sativum L) seeds for development of functional foods. Chapter 4. In: Advances in seed biology. Intech; 2017. p. 279-94.

26. Ghante MH, Badole SL, Bodhankar SL. Health benefits of garden cress (Lepidium sativum Linn) seed extracts. Nuts and Seeds in Health and Disease Prevention; 2011. p. 521-5.

27. Chatoui K, Talbaoui A, Aneb M, Bakri Y, Harhar H, Tabyaoui M. Phytochemical screening, the antioxidant and antibacterial activity of Lepidium sativum seeds from morocco. J Mater Environ Sci 2016;7:2938-46.

28. Ghalem BR, Ali. Preliminary phytochemical screening of five commercial essential oils. World J Appl Chem 2017;2:145-51.

29. Zia-Ul-Haq M, Ahmad S, Calani L, Mazzeo T, Del Rio D, Pellegrini $\mathrm{N}$, et al. Compositional study and antioxidant potential of Ipomoea hederacea Jacq and Lepidium sativum L seeds. Molecules 2012;17:10306-21.

30. Hussain I, Khattak MU, Riaz Ullah, Muhammad Z, Khan N, Khan FA, et al. Phytochemicals screening and antimicrobial activities of selected medicinal plants of Khyber Pakhtunkhwa, Pakistan. Afr J Pharm Pharmacol 2011;5:746-50.

31. Bryan RM, Shailesh NS, Jill KW, Steven FV, Roque LE. Composition and physical properties of cress (Lepidium sativum L) and field pennycress (Thlaspi arvense L) oils. Indus Crops Prod 2009;30:199-205.

32. Diwakara BT, Duttaa PK, Lokeshb BR, Naidu KA. Bioavailability and metabolism of n-3 fatty acid-rich garden cress (Lepidium sativum) seed oil in albino rats. Prostaglandins, Leukotrienes and Essential Fatty Acids 2008;78:123-30.

33. Alshammari GM, Yahya MA, Ahmed SB. Nutritive value of Elrashad (Lepidium sativum L) seeds grown in Saudi Arabia. J Exp Biol Agric Sci 2017;5(Suppl 1):S155-S158.

34. Abdel Karim M, Sufian A, Kamal MS, Inas O. Gc-Ms analysis and antimicrobial activity of fixed oil from Saudi Lepidium sativum (Crusifereae) seeds. Int J Adv Res 2017;5:1662-70.

35. Hussein HM. Analysis of trace heavy metals and volatile chemical compounds of Lepidium sativum using atomic absorption spectroscopy, gas chromatography-mass spectrometric and fourier-transform infrared spectroscopy. Res J Pharm Biol Chem Sci 2016;7:2529-55.

36. Nathawat RS, Mishra P, Patni V. Identification and qualitative analysis of $\beta$-sitosterol and some phytoestrogens in in vivo and in vitro samples of Lepidium sativum: a semi-arid bone healing plant. Biochem Pharmacol (Los Angel) 2015;4:5.

37. Kadam D, Palamthodi S, Lele SS. LC-ESI-Q-TOF-MS/MS profiling and antioxidant activity of phenolics from $L$. sativum seed cake. J Food Sci Technol 2018;55:1154-63.

38. Yadav YC, DN Srivastav, AK Seth, V Saini, R Balaraman, TK Ghelani. In vivo antioxidant potential of Lepidium sativum seeds in albino rats using cisplatin induced nephrotoxicity. Int J Phytomed 2010;2:292-8.

39. Sakran M, Selim Y, Zidan N. A new isoflavonoid from seeds of Lepidium sativum $\mathrm{L}$ and its protective effect on hepatotoxicity induced by paracetamol in male rats. Molecules 2014;19:15440-15551.

40. Maier UH, Gundlach H, Zenk MH. Seven imidazole alkaloids from Lepidium sativum. Phytochemistry 1998;49:1791-5.

41. Radwan HM, El-Missiry MM, Al-Said WM, Ismail AS, Abdel Shafeek, Seif-El-Nasr MM. Investigation of the glucosinolates of Lepidium sativum growing in Egypt and their biological activity. Res J Medicine Med Sci 2007;2:127-32.

42. Golkar P, Hadian F, Koohi Dehkordi M. Production of a new mucilage compound in Lepidium sativum callus by optimizing in vitro growth conditions. Nat Prod Res 2018;15:1-6.

43. Singh AS, Singh SK. Phytoconstituents estimation of Lepidium sativum L seeds extracts using GC-MS spectroscopy. World J Pharm Res 2018;7:1360-7.

44. Abuelgasim AI, Ali MI, Hassan A. Antimicrobial activities of extracts for some of the medicinal plants. Int J Adv Appl Sci 2015;2:1-5.

45. Abushady HM, El-Shatoury EH, Al-Shimaa SA. Antimicrobial and antioxidant properties of some selected Egyptian plants. Ann Mechnikov Institute 2016;4:71-95.
46. Bhasin P, Bansal D, Punia A, Sehrawat AR. Antimicrobial activities of Lepidium sativum: medicinal plant used in folklore remedies in India. J Pharm Res 2012;5:1643-5.

47. Mishra N, Mohammed A, Rizvi SI. Efficacy of Lepidium sativum to act as an anti-diabetic agent. Prog Health Sci 2017;17:44-53.

48. Attia ES, Amer AH, Hasanein MA. The hypoglycemic and antioxidant activities of garden cress (Lepidium sativum L) seed on alloxan-induced diabetic male rats. Nat Prod Res 2017;13:1-5.

49. Shukla AK, Bigoniya P, Srivastava B. The hypoglycemic activity of Lepidium sativum Linn seeds total alkaloid on alloxaninduced diabetic rats. Res J Med Plant 2012;6:587-96.

50. Eddouks M, Maghrani M, Zeggwagh NA, Michel JB. Study of the hypoglycaemic activity of Lepidium sativum $\mathrm{L}$ aqueous extract in normal and diabetic rats. J Ethnopharmacol 2005; 97:391-5.

51. Eddouks M, Maghrani M. Effect of Lepidium sativum L on renal glucose reabsorption and urinary TGF-beta 1 levels in diabetic rats. Phytother Res 2008;22:1-5.

52. Naji NS, Abood FN. Effect of tocopherol extraction of Lepidium sativum seeds in sperm parameters of white male rabbits. J Biol Agric Healthcare 2013;3:43-9.

53. Kamani M, Hosseini ES, Kashani HH, Atlasi MA, Nikzad H. Protective effect of Lepidium sativum seed extract on histopathology and morphology of epididymis in the diabetic rat model. Int J Morphol 2017;35:603-10.

54. Kamani M, Mhabadi JA, Atlasi MA, Seyedi F, Kamani E, Nikzad H. Protective effect of alcoholic extract of garden cress seeds on the histopathological changes of the ventral prostate in streptozotocin diabetic rats. Int J Morphol 2017;35:1178-84.

55. Ibraheem SR, Ibraheem MR, Hashim SS. Effect of Lepidium sativum aqueous crude extract in some fertility parameters in mice. Int J Sci Res 2017;6:260-6.

56. Westphal JP. Lepidium sativum effects on reproduction and visceral organ development in sprague-dawley rats. MS thesis, St. Cloud State University; 2017.

57. Kagathara VG, Shah KK, Anand IS. Effect of methanolic extract of seeds of Lepidium sativum Linn on proceptive and receptive behaviors of female rats. IJPPR Human 2015;4:101-12.

58. Imade OV, Erinfolami WA, Ajadi RA, Abioja MO, Rahman SA, Smith OF, et al. Effects of Lepidium sativum supplementation on growth and gonadotropins secretion in ovariectomized, estrogen-implanted rabbits. Asian Pacific J Rep 2018;7:155-60.

59. Rehman NU, Mehmood MH, Alkharfy KM, Gilani AH. Prokinetic and laxative activities of Lepidium sativum seed extract with species and tissue-selective gut stimulatory actions. J Ethnopharmacol 2011;134:878-83.

60. Manohar D, Lakshman K, Shylaja H, Viswanatha GL, Rajesh, Nandakumar K. Antidiarrheal activity of methanolic extracts of seeds of Lepidium sativum. J Nat Rem 2009;9:197-201.

61. Rehman NU, Mehmood MH, Alkharfy KM, Gilani AH. Studies on antidiarrheal and antispasmodic activities of Lepidium sativum crude extract in rats. Phytother Res 2012;26:136-41.

62. Gilani AH, Rehman NU, Mehmood MH, Alkharfy KM. Species differences in the antidiarrheal and antispasmodic activities of Lepidium sativum and insight into underlying mechanisms. Phytother Res 2013;27:1086-94.

63. Masadeh MM, Alkofahi AS, Alzoubi KH, Tumah HN, Bani-Hani K. Anti-Helicobactor pylori activity of some Jordanian medicinal plants. Pharm Biol 2014;52:566-9.

64. Mali RG, Mahajan SG, Mehta AA. Studies on bronchodilatory effect of Lepidium sativum against allergen-induced bronchospasm in guinea pigs. Pharmacogn Magazine 2008;4:189-92.

65. Paranjape AN, Mehta A. A study on clinical efficacy of Lepidium sativum seeds in the treatment of bronchial asthma. Iran J Pharmacol Ther 2006;5:55-9.

66. Rehman NU, Khan A, Alkharfy KM, Gilani AH. Pharmacological basis for the medicinal use of Lepidium sativum in airways disorders. J Evidence-Based Complementary Altern Med 2012. http://dx.doi.org/10.1155/2012/596524

67. Ahmad A, Jan BL, Raish M, Alkharfy KM, Ahad A, Khan A, et al. Inhibitory effects of Lepidium sativum polysaccharide extracts on TNF- $\alpha$ production in Escherichia coli-stimulated mouse. Biotech 2018;8:286.

68. Diwakar PT, Datta PK, Belur RL, Naidu KA. Modulatory effect of $\alpha$-linolenic acid-rich garden cress (Lepidium sativum L) seed oil 
on inflammatory mediators in adult albino rats. $\mathrm{Br} J$ Nutr 2011;106:530-9.

69. Sowjanya KRR, Vishweswar RV, Bushra F, Kapila M, Srilakshmi M. In vitro anti-inflammatory activity of ultra soni assisted, methanol extract of Lepidium sativum Linn seeds. Int J Pharm Dev Technol 2013;3:63-5.

70. Ozdemir H, Yaren B, Oto G. Antinociceptive activity of aqueous extract of Lepidium sativum $\mathrm{L}$ in mice. Eastern J Med 2015;20:131-5.

71. Raval ND, Pandya TN. Clinical trial of Lepidium sativum Linn (Chandrashura) in the management of sandhivata (osteoarthritis). Int Quarterly J Res Ayurveda 2009;30:153-7.

72. Vohora SB, Khan MS. Pharmacological studies on Lepidium sativum linn. Indian J Physiol Pharmacol 1977;21:118-20.

73. Mali RG, Mahajan SG, Mehta AA. Lepidium sativum (Garden cress): a review of contemporary literature and medicinal properties. Oriental Pharm Exp Med 2007;7:331-5.

74. Maghrani M, Zeggwagh NA, Michel JB, Eddouks M. Antihypertensive effect of Lepidium sativum L. in spontaneously hypertensive rats. J Ethnopharmacol 2005; 100:193-7.

75. Patel U, Kulkarni M, Undale V, Bhosale A. Evaluation of diuretic activity of aqueous and methanol extracts of Lepidium sativum garden cress (Cruciferae) in rats. Trop J Pharm Res 2009;8:215-9.

76. Selek S, Koyuncu I, Caglar HG, Bektas I, Yilmaz MA, Gonel A, et al. The evaluation of antioxidant and anticancer effects of Lepidium sativum subsp spinescens L methanol extract on cancer cells. Cell Mol Biol (Noisy-le-grand) 2018;64:72-80.

77. Malar J, Chairman K, Singh ARJ, Vanmathi JS, Balasubramanian A, Vasanthi K. Antioxidative activity of different parts of the plant Lepidium sativum Linn. Biotechnol Rep (Amst) 2014;3:95-8.

78. Bhasin P, Bansal D, Yadav OP, Punia A. In vitro antioxidant activity and phytochemical analysis of seed extracts of Lepidium sativum-a medicinal herb. J Biosci Tech 2011;2:410-5.

79. Kassabe PJ, Patil P, Kamble DD, Dandge P. Nutritional, elemental analysis and antioxidant activity of garden cress (Lepidium sativum L) seeds. Int J Pharm Pharm Sci 2012;4:392-5.

80. Aslani E, Naghsh N, Ranjbar M. Cytotoxic effects of hydroalcoholic extracts of cress (Lepidium sativum)-made from different stages of the plant-on k562 Leukemia cell line. Hormozgan Med J 2014;18:370-8.

81. Indumathy R, Aruna A. Cytotoxic potential of various extracts of Lepidium sativum (Linn)-an in vitro evaluation. Int J Pharmacol Pharm Sci 2015;2:1-5.

82. Ait-Yahia O, Bouzroura SA, Belkebir A, Kaci S, Aouichat AB. Cytotoxic activity of flavonoid extracts from Lepidium sativum (Brassicaceae) seeds and leaves. Int J Pharmacogn Phytochem Res 2015;7:1231-5.

83. Mahassni SH, Al-Reemi RM. Apoptosis and necrosis of human breast cancer cells by an aqueous extract of garden cress (Lepidium sativum) seeds. Saudi J Biol Sci 2013;20:131-9.

84. Raish M, Ahmad A, Alkharfy KM, Ahamad SR, Mohsin K, AlJenoobi FI, et al. Hepatoprotective activity of Lepidium sativum seeds against D-galactosamine/lipopolysaccharideinduced hepatotoxicity in animal model. BMC Complement Altern Med 2016;16:501.
85. Al-Asmari AK, Athar MT, Al-Shahrani HM, Al-Dakheel SI, AlGhamdi MA. Efficacy of Lepidium sativum against carbon tetrachloride-induced hepatotoxicity and determination of its bioactive compounds by GC-MS. Toxicol Rep 2015;2:1319-26.

86. Afaf I, Abuelgasim, Nuha HS, Mohammed AH. Hepatoprotective effect of Lepidium sativum against carbon tetrachloride induced damage in rats. Res J Animal Veterinary Sci 2008;3:20-3.

87. Al-Sheddi ES, Farshori NN, Al-Oqail MM, Musarrat J, AlKhedhairy AA, Siddiqui MA. Protective effect of Lepidium sativum seed extract against hydrogen peroxide-induced cytotoxicity and oxidative stress in human liver cells (HepG2). Pharm Biol 2016;54:314-21.

88. Shinde N, Jagtap A, Undale V, Kakade S, Kotwal S, Patil R. Protective effect of Lepidium sativum against doxorubicininduced nephrotoxicity in rats. Res J Pharm Biol Chem Sci 2010;3:42-9.

89. Yadav YC, Srivastav DN, Seth AK, Saini V, Yadav KS. The nephropharmacological activity of ethanolic extract Lepidium sativum $\mathrm{L}$ seeds in albino rats using cisplatin-induced acute renal failure. Int J Pharm Sci Rev Res 2010;4:64-8.

90. Halaby MS, Farag MH, Mahmoud SAA. Protective and curative effects of garden cress seeds on acute renal failure in male albino rats. Middle East J Appl 2015;5:573-86.

91. Kassie F, Rabot S, Uhl M, Huber W, Qin HM, Helma C, et al. Chemoprotective effects of garden cress (Lepidium sativum) and its constituents towards 2-amino-3-methyl-imidazo[4,5-f] quinoline (Iq)-induced genotoxic effects and colonic preneoplastic lesions. Carcinogenesis 2002;23:1155-61.

92. Shukla A, Chandra SS, Papiya B. Phytochemical and CNS activity of Lepidium sativum Linn seeds total alkaloid. Scholar Res Library 2011;3:226-37.

93. Althnaian T. Influence of dietary supplementation of Garden cress (Lepidium sativum L) on liver histopathology and serum biochemistry in rats fed high cholesterol diet. J Adv Vet Anim Res 2014;1:216-23.

94. Amawi K, Aljamal A. Effect of Lepidium sativum on lipid profiles and blood glucose in rats. J Physiol Pharmacol Adv 2012;2:27781.

95. Juma AB. The effects of Lepidium sativum seeds on fractureinduced healing in rabbits. Med Gen Med 2007;9:23.

96. Datta PK, Diwakar BT, Viswanatha S, Murthy KN, Naidu KA. Safety evaluation studies on garden cress (Lepidium sativum L) seeds in Wistar rats. Int J Appl Res Nat Prod 2011;4:37-43.

97. Adam SEI. Effects of various levels of dietary Lepidium sativum L seeds in rats. Am J Chin Med 1999;27:397-405.

98. Bafeel SO, Ali SS. The potential liver toxicity of Lepidium sativum seeds in albino rats. Plant Physiol 2009;4:1250-8.

99. Al-Sheddi ES, Farshori NN, Al-Oqail MM, Musarrat J, AlKhedhairy AA, Siddiqui MA. Evaluation of cytotoxicity and oxidative stress induced by alcoholic extract and oil of Lepidium sativum seeds in human liver cell line HepG2. Afr J Biotechnol 2013;12:3854-63.

100. Mahassni SH, Khudauardi ER. A pilot study: the effects of an aqueous extract of Lepidium sativum seeds on levels of immune cells and body and organs weights in mice. J Ayurvedic Herbal Med 2017;3:27-32. 